\title{
Direct Long-Term Effects of L-Asparaginase on Rat and Human Pancreatic Islets
}

\author{
NIELS CLAUSEN AND JENS HØIRIIS NIELSEN \\ University Clinics of Paediatrics, University Hospital of Copenhagen, Copenhagen; and the Hagedorn Research \\ Laboratory, Gentoffe, Denmark
}

\begin{abstract}
L-Asparaginase, an effective agent in the treatment of acute lymphoblastic leukemia, may induce a diabetic state. The pathogenesis of the diabetogenic effect was studied in cultured pancreatic islets. Mean serum concentrations in three children with acute lymphoblastic leukemia were $2.4 \mathrm{U} / \mathrm{mL}$ (range 1.4-4.5) before and 31.5 $\mathrm{U} / \mathrm{mL}$ (range 18.6-51.8) immediately after an intravenous injection of $1000 \mathrm{U} / \mathrm{kg}$ L-asparaginase. Glucose-induced insulin release from pancreatic islets of rat and man was measured after 3 and 7 days of culture in media with or without clinically relevant concentrations of Escherichia coli L-asparaginase $(0.01-100 \mathrm{U} / \mathrm{mL})$. After culture, the remaining insulin, glucagon, and DNA in the islets were determined. After 7 days of culture of adult rat or human islets, both the accumulation of insulin in the medium and the content of insulin and glucagon in the islets were significantly reduced in the presence of $100 \mathrm{U} / \mathrm{mL} \mathrm{L-}$ asparaginase compared with controls. Addition of $10^{-6} \mathrm{M}$ hydrocortisone to the culture medium enhanced this effect. In newborn rat islets a significant reduction in insulin release and content was observed already in the presence of $0.1 \mathrm{U} / \mathrm{mL}$ asparaginase, whereas the glucagon content was unchanged. Removal of the drug resulted in partial recovery of the insulin secretion. To elucidate the mechanisms of action of the drug, insulin biosynthesis was studied in islets cultured in asparagine-free medium with or without asparaginase. No difference in biosynthesis was seen between media with or without asparagine, whereas $0.1 \mathrm{U} /$ $\mathrm{mL}$ asparaginase caused about a $50 \%$ reduction under both conditions. These results indicate that the pancreatic $\beta$ cells are particularly sensitive to $L$-asparaginase, suggesting that the diabetogenic effect of the drug is exerted by a direct interaction with the pancreatic $\beta$-cell and is not due to lack of exogenous supply of asparagine. (Pediatr Res 26: 158-161, 1989)
\end{abstract}

$\mathrm{L}$-Asparaginase is an established drug for the induction or consolidation of remission in children with acute lymphoblastic leukemia. A major side effect of $\mathrm{L}$-asparaginase treatment is nonketotic hyperglycemia and glycosuria, which have been reported in $10 \%$ of children receiving $10000 \mathrm{IU} / \mathrm{m}^{2}$ two to four times in the induction treatment in conjunction with prednisone (1). The mechanism of the hyperglycemia is not known, but a rational approach to the treatment of this adverse effect of $\mathrm{L}-$ asparaginase requires clarification of the pathogenesis. Decrease in insulin synthesis $(2,3)$, reduction in insulin release (4), and reduction of the number of insulin receptors (5) have been

Received August 9, 1988; accepted December 15, 1988.

Correspondence Jens H申iriis Nielsen, Hagedorn Research Laboratory, Niels Steensensvej 6, DK-2820 Gentoffe, Denmark. proposed. In previous in vitro studies only acute effects were measured, and extremely high doses of the drug were used (6). The aim of our study was, therefore, to elucidate the direct longterm effect of clinically relevant concentrations of $\mathrm{L}$-asparaginase on the insulin release and biosynthesis in isolated rat and human pancreatic islets in culture.

\section{MATERIALS AND METHODS}

Asparaginase activity in treated children. In three children with acute lymphoblastic leukemia, blood samples were drawn before and immediately after injection of Escherichia coli-L-asparaginase-2 (EC 3.5.1.1) (Crasnitin, Bayer, Leverkusen, West Germany) $1000 \mathrm{IU} / \mathrm{kg}$ body wt/day intravenously for 10 days to consolidate the remission, which had been induced by vincristin $2 \mathrm{mg} / \mathrm{m}^{2}$ weekly and prednisone $60 \mathrm{mg} / \mathrm{m}^{2}$ daily in 5 wk. Sera were stored at $-20^{\circ} \mathrm{C}$ until analyzed before $1 \mathrm{mo}$ in the same assay. L-Asparaginase activity in serum is stable for at least 3 mo under these conditions.

Asparaginase assay. The asparagine assay was performed according to the method described (7). A total of $40 \mu \mathrm{L}$ of 6.13 $\mathrm{mM}$ asparagine containing $7.1 \mu \mathrm{Ci} / \mathrm{mL} \mathrm{L}-\left[{ }^{14} \mathrm{C}\right]$ asparagine $(120$ $\mathrm{mCi} / \mathrm{mmol}$ ) The Radiochemical Centre, Amersham, England) were incubated for $10 \mathrm{~min}$ with $10 \mu \mathrm{L}$ serum. The reaction was stopped and protein precipitated with $75 \mu \mathrm{L}$ ice cold $99 \%$ (w/w) ethanol. Asparagine and aspartic acid were separated by thinlayer chromatography on resin-coated plates in ethylacetate in water $(8: 92)$. The fraction of asparagine converted to aspartic acid was then determined by liquid scintillation counting of the eluted spots. The conversion fraction asparagine/asparagine + aspartic acid indicated the asparaginase activity in the sample when compared to known controls. One unit is defined as the amount of enzyme which converts $1 \mu \mathrm{mol} \mathrm{L}$-asparagine/min.

Islet isolation and culture. Pancreatic islets were isolated from 3 - to 5-d-old (newborn) and 30-d-old (adult) rats by the collagenase method as described (8). Briefly, pancreas was treated by $1 \mathrm{mg} / \mathrm{mL}$ collagenase from Clostridium histolyticum (Boehringer Mannheim, West Germany) in Hanks' balanced salt solution (Flow Laboratories, Irvine, Scotland) supplemented with 100000 $\mathrm{U} / \mathrm{L}$ penicillin, $100 \mathrm{mg} / \mathrm{L}$ streptomycin, and $20 \mathrm{mM} \mathrm{N}$-2-hydroxyethylpiperazine- $N^{\prime}$-2-ethanesulfonic acid for $15 \mathrm{~min}$ at $37^{\circ} \mathrm{C}$, washed in cold HBSS, and purified on a Percoll (Pharmacia, Uppsala, Sweden) gradient followed by hand-picking under a dissecting microscope.

Human islets were isolated from the pancreas of necro-kidney donors as described (9). Pancreases from kidney donors were transported to the laboratory and treated with collagenase within $1 \mathrm{~h}$ after removal. Pieces of the pancreas were treated repeatedly with $1-2 \mathrm{mg} / \mathrm{ml}$ collagenase. After each $10-$ to 20 -min period the supernatants were removed and washed in cold Hanks' balanced salt solution. Islets were hand-picked under the microscope. The isolated islets were maintained in culture medium RPMI 1640 supplemented with $10 \%$ newborn calf serum for 
$1-2 \mathrm{~d}$ before the experiments. About 50 islets were placed in Petri dishes with RPMI 1640 containing $8.5 \mathrm{mmol} / \mathrm{L}$ glucose and $0.5 \%$ normal human serum. Crasnitin was added in the proper dilution and the islets were incubated in a humidified atmosphere at $37^{\circ} \mathrm{C}$. In some experiments the medium was prepared from the individual constituents with omission of Lasparagine (RPMI 1640 Select-amine-kit, Gibco, Paisley, Scotland). Medium was changed every 3 or $4 \mathrm{~d}$ and stored for insulin determination. No degradation of insulin took place under these culture conditions. After the culture period the islets were collected and sonicated. The homogenates were assayed for insulin, glucagon and DNA.

Insulin biosynthesis. Islets were incubated for $3 \mathrm{~h}$ in HBSS containing $1 \mathrm{mg} / \mathrm{mL}$ human serum albumin and $500 \mu \mathrm{Ci} / \mathrm{mL}$ 4,5-[ $\left.{ }^{3} \mathrm{H}\right]$-leucine ( $130 \mathrm{mCi} / \mathrm{mM}$, The Radiochemical Centre) The islets were washed in Hanks' balanced salt solution containing $10 \mathrm{mM}$ leucine, homogenized by sonication, and immunoprecipitated with guinea pig antiinsulin serum overnight followed by 30 -min incubation with protein-A-Sepharose (Pharmacia) as described (10). The precipitate was washed, dissolved in acetic acid, transferred to a scintillation vial with Aquasol-2 (New England Nuclear, Boston, MA), and counted in a scintillation counter.

Analytical methods. Insulin was determined by RIA, using crystalline rat insulin (Novo Research Laboratory, Bagsvaerd, Denmark) as standard in rat islet experiments and highly purified porcine insulin (Nordisk Gentoffe A/S, Gentoffe Denmark) as standard in human islet experiments. Glucagon was determined by a RIA kit (Novo). DNA was determined by a fluorometric assay (11). Wilcoxon's test was used for the statistical evaluation.

\section{RESULTS}

The mean activity of asparaginase in serum during leukemia treatment was $2.6 \mathrm{U} / \mathrm{mL}$ (range 1.4-4.5) before and $31.5 \mathrm{U} / \mathrm{mL}$ (range 18.6-51.8) immediately after an intravenous injection of L-asparaginase. None of the these patients had hyperglycemia or glucosuria during induction of remission or consolidation.

The dose dependency of asparaginase was evaluated in islets from newborn rats (Table 1). A significant reduction in insulin release and content was seen already at $0.1 \mathrm{U} / \mathrm{mL}$. The glucagon and DNA content of the islets were not affected by this dose, although $1 \mathrm{U} / \mathrm{mL}$ or higher doses resulted in disintegration of the islets (data not shown).

To study the reversibility of the asparaginase effect, newborn rat islets were exposed to $0.1 \mathrm{U} / \mathrm{mL}$ for $7 \mathrm{~d}$, after which asparaginase was removed and the islets cultured for another $7 \mathrm{~d}$ (Fig. 1). Insulin release was significantly higher $7 \mathrm{~d}$ after removal of the drug than from islets exposed continuously to asparaginase $(p<0.05)$. The insulin content was not significantly elevated (Table 2).

The combined effect of $\mathrm{L}$-asparaginase, $100 \mathrm{U} / \mathrm{mL}$, and hydrocortisone $10^{-6} \mathrm{~mol} / \mathrm{L}$, was studied on adult rat islets (Fig. 2). Asparaginase almost abolished the insulin release, whereas hydrocortisone had a significant effect only on d 7. A similar difference was found on the content of both insulin and glucagon in the islets after culture (Table 3). The combination of the two

Table 1. Effect of 0.01 and $0.1 \mathrm{U} / \mathrm{mL}$ L-asparaginase (ASNase) on insulin release and insulin, glucagon, and DNA content of

\begin{tabular}{|c|c|c|c|c|}
\hline $\begin{array}{l}\text { ASNase } \\
(\mathrm{U} / \mathrm{mL})\end{array}$ & $\begin{array}{c}\text { Insulin release } \\
(\mathrm{ng} / \text { islet } \\
\times 7 \mathrm{~d})\end{array}$ & $\begin{array}{l}\text { Insulin } \\
\text { content } \\
\text { (ng/islet) }\end{array}$ & $\begin{array}{l}\text { Glucagon } \\
\text { content } \\
\text { (ng/islet) }\end{array}$ & $\begin{array}{c}\text { DNA } \\
\text { content } \\
\text { (ng/islet) }\end{array}$ \\
\hline 0 & $91.4 \pm 5$ & $17.4 \pm 2.3$ & $0.21 \pm 0.03$ & $10.0 \pm 0.9$ \\
\hline 0.01 & $96.4 \pm 10.8$ & $19.2 \pm 2.0$ & $0.25 \pm 0.03$ & $12.7 \pm 0.6$ \\
\hline 0.1 & $56.9 \pm 4.9^{*}$ & $9.4 \pm 1.9^{*}$ & $0.26 \pm 0.03$ & $11.9 \pm 1.3$ \\
\hline
\end{tabular}

$* p<0.05$.

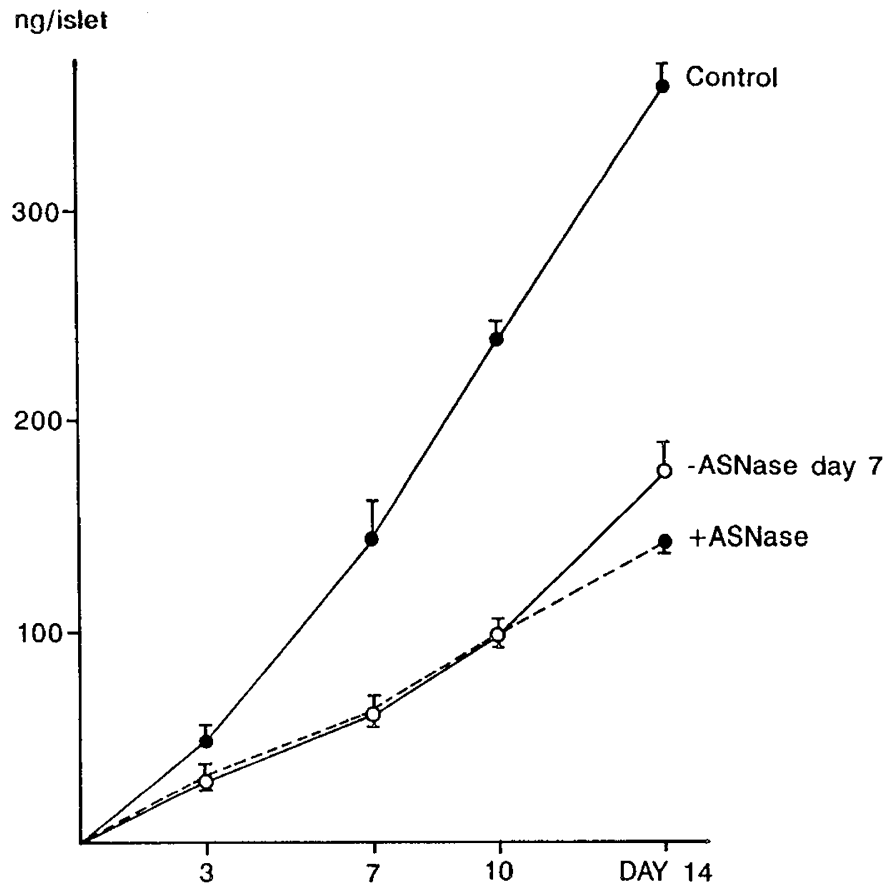

Fig. 1. Cumulative insulin release during $14 \mathrm{~d}$ of newborn rat pancreatic islets in culture with $0.1 \mathrm{U} / \mathrm{mL}$ L-asparaginase either during all $14 \mathrm{~d}$ of the experiment $(+A S N a s e)$ or during the first $7 \mathrm{~d}$ of the 14-d experiment $(-$ ASNase $d 7)$. Significant differences $(p<0.05)$ were observed on $\mathrm{d} 7,10$, and 14 between control and ASNase groups, and on $\mathrm{d} 14$ between +ASNase and -ASNase $\mathrm{d} 7$ groups.

Table 2. Reversibility of effect of $0.1 \mathrm{U} / \mathrm{mL}$ L-asparaginase on insulin content and DNA content of newborn rat islets; culture for $7 d$ with asparaginase followed by $7 d$ in asparaginase-free medium (mean $\pm S E M, n=6$ )

$\left.\begin{array}{llc}\hline & \begin{array}{c}\text { Insulin } \\ \text { content } \\ \text { (ng/islet) }\end{array} & \begin{array}{c}\text { DNA } \\ \text { content } \\ \text { (ng/islet) }\end{array} \\ \hline \text { Control } & 9.3 \pm 2.2 & 14.4 \pm 2.3 \\ \left.\begin{array}{l}\text { Asparaginase d 0-14 } \\ \text { Asparaginase d 0-7 }\end{array}\right\} & 7.0 \pm 1.8^{*} & 14.9 \pm 1.9 \\ \text { No asparaginase d 8-14 }\end{array}\right\}$

* vs control $p<0.05$.

drugs resulted in an even more marked effect than either compound alone. No significant change in DNA content was seen.

The effect of $100 \mathrm{U} / \mathrm{mL}$ of L-asparaginase was studied in islets isolated from three human kidney donors. Both insulin release and content were markedly depressed by exposure to L-asparaginase, whereas DNA content was unchanged (Table 4).

To elucidate the mechanism behind the effect of L-asparaginase, insulin biosynthesis was studied in rat islets cultured in media with or without asparagine. No difference was seen in control islets, whether or not asparagine was present (Table 5), whereas $0.1 \mathrm{U} / \mathrm{mL}$-asparaginase resulted in a $50 \%$ decrease of insulin biosynthesis under both conditions (Table 5).

\section{DISCUSSION}

Several mechanisms have been suggested to explain the hyperglycemic action of L-asparaginase in man. Both normal and decreased glucose tolerance have been described, as well as normal and decreased insulin levels in serum (2-4). Reduced binding of insulin to monocytes from L-asparaginase-treated patients suggested a reduced peripheral action of insulin (5). 


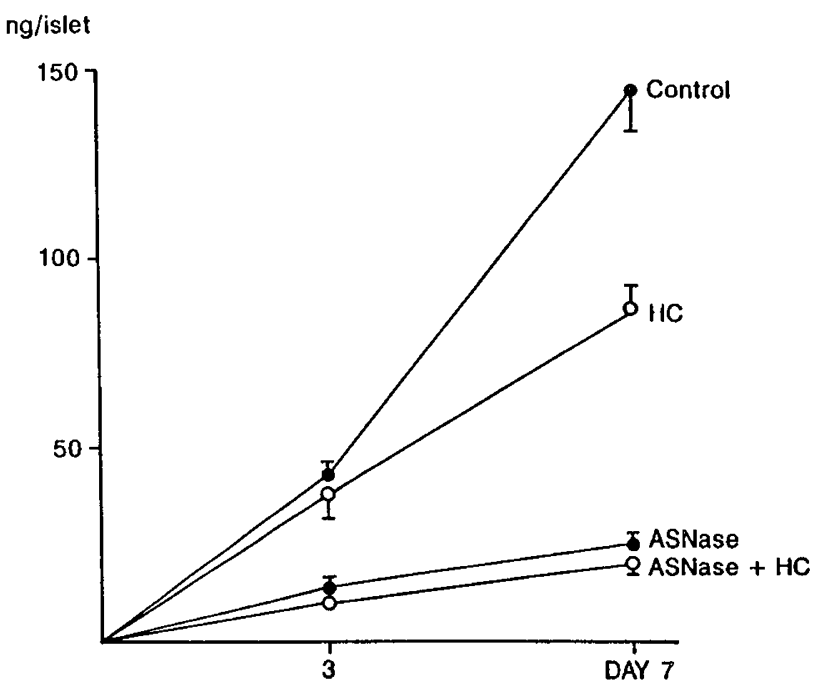

Fig. 2. Cumulative insulin release during $7 \mathrm{~d}$ of adult rat pancreatic islets in culture with $10^{-6} \mathrm{M}$ hydrocortisone $(H C)$ or $100 \mathrm{U} / \mathrm{mL} \mathrm{L-}$ asparaginase (ASNase) or both (ASNase $+H C)$. Significant differences $(p<0.05)$ were observed on 7 between control, HC, and ASNase + HC groups.

Table 3. Effect of $10^{-6} \mathrm{M}$ hydrocortisone and $100 \mathrm{U} / \mathrm{mL} \mathrm{L-}$ asparaginase either alone or in combination on insulin glucagon, and DNA content of adult rat islets in culture (mean $\pm S E M, n=6$ )

\begin{tabular}{|c|c|c|c|}
\hline & $\begin{array}{l}\text { Insulin } \\
\text { content } \\
\text { (ng/islet) }\end{array}$ & $\begin{array}{c}\text { Glucagon } \\
\text { content } \\
\text { (ng/islet) }\end{array}$ & $\begin{array}{c}\text { DNA } \\
\text { content } \\
\text { (ng/islet) }\end{array}$ \\
\hline Control & $18.6 \pm 2.4$ & $0.73 \pm 0.17$ & $10.5 \pm 0.9$ \\
\hline Hydrocortisone & $14.8 \pm 2.7$ & $0.36 \pm 0.07^{*}$ & $9.7 \pm 1.0$ \\
\hline $\begin{array}{l}\text { L-asparaginase } \\
\text { Hydrocortisone }\end{array}$ & $7.3 \pm 1.2^{*}$ & $0.10 \pm 0.05^{*}$ & $10.2 \pm 1.3$ \\
\hline $\begin{array}{l}+ \\
\text { L-asparaginase }\end{array}$ & $5.0 \pm 0.7^{*}$ & $0.06 \pm 0.03^{*}$ & $8.0 \pm 0.9$ \\
\hline
\end{tabular}

* vs control $p<0.05$.

Table 4. Effect of $100 \mathrm{U} / \mathrm{mL}$ L-asparaginase (ASNase) on insulin release and insulin and DNA content of isolated human islets in culture

\begin{tabular}{|c|c|c|c|c|c|c|}
\hline \multirow{2}{*}{$\begin{array}{l}\text { Donor } \\
\text { age (y) }\end{array}$} & \multicolumn{2}{|c|}{$\begin{array}{l}\text { Insulin release } \\
(\mathrm{ng} / \text { islet } \times 7 \mathrm{~d})\end{array}$} & \multicolumn{2}{|c|}{$\begin{array}{c}\text { Insulin content } \\
\text { (ng/islet) }\end{array}$} & \multicolumn{2}{|c|}{$\begin{array}{l}\text { DNA content } \\
\text { (ng/islet) }\end{array}$} \\
\hline & Control & ASNase & Control & ASNase & Control & ASNase \\
\hline 11 & 32.8 & 2.5 & 3.7 & 0.7 & 18.8 & 27.6 \\
\hline 39 & 26.0 & 5.8 & 9.8 & 3.6 & 14.7 & 17.1 \\
\hline 44 & 30.7 & 5.8 & 19.1 & 3.4 & 19.8 & 12.7 \\
\hline
\end{tabular}

Table 5. Effect of $0.1 \mathrm{U} / \mathrm{mL}$ L-asparaginase (ASNase) on insulin release and biosynthesis after culture in medium with or without asparagine (mean $\pm S E M, n=6$ )

\begin{tabular}{ccccc}
\hline & & & & Proinsulin \\
Medium & $\begin{array}{c}0.1 \mathrm{U} / \\
\mathrm{mL}\end{array}$ & $\begin{array}{c}\text { Insulin release } \\
\text { biosynthesis } \\
\text { (\% of total } \\
\text { asparagine }\end{array}$ & $\begin{array}{c}\text { Insulin } \\
\text { content } \\
(\mathrm{ng} / \text { islet })\end{array}$ & $\begin{array}{c}\text { protein bio- } \\
\text { synthesis) }\end{array}$ \\
\hline+ & - & $108.5 \pm 6.2$ & $71.1 \pm 9.0$ & $33.3 \pm 2.0$ \\
+ & + & $37.8 \pm 4.1^{*}$ & $29.3 \pm 3.2^{*}$ & $15.8 \pm 1.4^{*}$ \\
- & - & $108.2 \pm 13.3$ & $60.2 \pm 4.5$ & $30.0 \pm 1.0$ \\
- & + & $37.8 \pm 4.9^{*}$ & $27.3 \pm 4.6^{*}$ & $14.8 \pm 1.1^{*}$ \\
\hline$* p<0.05$ & & & &
\end{tabular}

In animal experiments L-asparaginase also induced hyperglycemia (12) associated with hyperinsulinemia when a single dose was given (13), but with decreased insulin levels after prolonged treatment (14). Previous studies on isolated rabbit islets in short term incubation showed a reduced glucose induced insulin release only after exposure to very high doses of L-asparaginase, i.e. $1000-10000 \mathrm{U} / \mathrm{mL}(6)$. Similar results were reported in rat islets incubated with $1000 \mathrm{U} / \mathrm{mL}(15)$.

Inasmuch as the L-asparaginase treatment most often is applied to children with acute lymphoblastic leukemia, the effect of the drug was primarily tested in islets from newborn rats. These islets appeared to be very sensitive to L-asparaginase since already 0.1 $\mathrm{U} / \mathrm{mL}$ reduced the insulin release (Table 1), whereas higher concentrations resulted in disintegration of the islets. At least a partial reversibility was observed about 4 to $7 \mathrm{~d}$ after removal of L-asparaginase (Fig. 1; Table 2), which is in agreement with both clinical observations (16) and animal experiments (6). The high sensitivity of the newborn rat islets may be due to the lower asparagine synthetase activity in the pancreas compared with older animals (17)

Adult rat islets were also affected, although at a higher dose of L-asparaginase (Fig. 2; Table 3). Addition of hydrocortisone, however, potentiated the inhibitory effect in analogy with the combined treatment of L-asparaginase and prednisone in man and in rabbits (18). Hydrocortisone was previously shown to influence glucose-induced insulin release and content in a bimodal manner on both mouse (19) and rat (20) islets in culture.

Because human islets are difficult to obtain due to scarcity of material, great variability of the pancreatic tissue and difficulties in the isolation and identification procedures (9), it was only possible to test the effect of $\mathrm{L}$-asparaginase in three cases which essentially confirmed the results found in rat islets (Table 4).

The concomitantly observed decrease in insulin release and insulin content of the islets cultured with L-asparaginase suggested that the drug affects insulin biosynthesis. This was also found to be the case (Table 5), but apparently the effect was not due to degradation of exogenous asparagine, because no effect on either release or insulin biosynthesis was seen by omission of this amino acid from the culture medium.

Although the glucagon content also was reduced in the adult rat islets exposed to $100 \mathrm{U} / \mathrm{mL} \mathrm{L}$-asparaginase, this was not seen in the newborn islets that were only exposed to $0.1 \mathrm{U} / \mathrm{mL}$, indicating that the $\beta$-cells are more sensitive to the drug than are the $\alpha$-cells. The lack of influence on the DNA content and the partial reversibility of the effect may suggest that the L-asparaginase does not kill the $\beta$-cells but rather inhibits insulin biosynthesis and release.

In conclusion, pancreatic $\beta$-cells appear to be particularly sensitive to $L$-asparaginase which may not be due to lack of exogenous asparagine. Whether a direct action on the cell membrane is involved remains to be studied. Thus the inhibitory effect of $\mathrm{L}$-asparaginase on $\beta$-cell function as well as on lymphocyte proliferation is still not explained (21).

Acknowledgments. The authors acknowledge the Departments of Urology at Rigshospitalet, University Hospital, Copenhagen, Denmark, and Glostrup Hospital, Glostrup, Denmark, for the provision of human pancreatic tissue for this study. We also thank Ragna J $\phi$ rgensen, Erna Engholm Pedersen, and Dagny Jensen for excellent technical assistance.

\section{REFERENCES}

1. Pui, CH, Burghen GA, Bowman WP, Aur RJA 1981 Risk factors for hyperglycemia in children with leukemia receiving $\mathrm{L}$-asparaginase and prednisone. $\mathbf{J}$ Pediatr 99:46-50

2. Whitecar JP, Bodey GP, Hill CS, Samaan NA 1970 Effect of $L$-asparaginase on carbohydrate metabolism. Metabolism 19:581-586

3. Gailani S, Nussbaum A, Ohnuma T, Freeman A 1971 Diabetes in patients treated with asparaginase. Clin Pharmacol Ther 12:487-490

4. Lavine RL, Brodsky C, Garofano CD, Rose LI 1978 The effect of E. coli Lasparaginase on oral glucose tolerance and insulin release in man. Diabetologia 15:113-1 16

5. Carpentieri U, Balch MT 1978 Hyperglycemia associated with the therapeutic 
use of $\mathrm{L}$-asparaginase. Possible role of insulin receptors. J Pediatr 93:775778

6. Lavine RL, DiCintio DM 1982 E. Coli L-asparaginase and insulin release in vitro. Metabolism 31:1009-1013

7. Clausen N, Christensen E 1986 Determination of L-asparaginase activity in serum by thin-layer chromatography: application to the treatment of acute lymphoblastic leukemia. Clin Chim Acta 161:111-116

8. Brunstedt J, Nielsen JH, Lernmark $\AA$, The Hagedorn Study Group 1984 Isolation of islets from mice and rats. In: Larner, J, Pohl S (eds) Methods in Diabetes Research, Vol I, part C. John Wiley \& Sons, New York, pp 245 258

9. Nielsen JH, Marner B, Bilde T, The Hagedorn Study Group 1984 Isolation and culture of adult human islets. In: Larner, J, Pohl S (eds) Methods in Diabetes Research, Vol I, part B. John Wiley \& Sons, New York, pp 227 234

10. Brunstedt J, Chan SJ 1982 Direct effect of glucose on the preproinsulin mRNA level in isolated pancreatic islets. Biochem Biophys Res Commun 106:13831389

11. Green IC, Taylor KW 1972 Effects of pregnancy in the rat on the size and insulin secretory response of the islets of Langerhans. J Endocrinol 54:317325

12. Khan A, Adachi M, Hill JM 1969 Diabetogenic effect of L-asparaginase. J Clin Endocrin 29:1373-1376
13. Lavine RL, DiCintio DM 1980 L-Asparaginase-induced diabetes mellitus in rabbits. Diabetes 29:528-531

14. Lavine RL, DiCintio DM 1984 L-Asparaginase diabetes mellitus in rabbits. Differing effects of two different schedules of L-asparaginase administration. Horm Metabol Res 16(suppl):92-96

15. Cervera T, de la Torre W, Perrez A, Pou JM 1987 E. coli asparaginase (L.A.) effects on insulin secretion from isolated rat islets of Langerhans. First European Congress on Endocrinology, Copenhagen, June 21-25, 1987 (abstr)

16. Onais SG, Whitecar JP, Hickey RC, Hill CS, Free E, Samaan NA 1970 The effect of L-asparaginase on carbohydrate metabolism. Fed Proc 29:831(abstr)

17. Milman HA, Coney DA, Young DM 1979 Role of pancreatic L-asparagine synthetase in homeostasis of $\mathrm{L}$-asparagine. Am J Physiol 236:E746-E753

18. Khan A, Adachi M, Hill JM 1970 Potentiation of diabetogenic effect of Lasparaginase by prednisolone. Horm Metab Res 2:275-276

19. Brunstedt J, Nielsen JH 1981 Direct long-term effect of hydrocortisone on insulin and glucagon release from mouse pancreatic islets in tissue culture. Acta Endocrinol 96:498-504

20. Nielsen JH 1983 Hormonal regulation and function of insulin producing cells in culture. In: Fischer, G, Wieser RJ (eds) Hormonally Defined Media. A Tool in Cell Biology. Springer Verlag, Berlin, pp 264-274

21. Kafkewitz D, Bendich A 1984 The inhibition of lymphocyte mitogenesis by asparaginase: a still unexplained phenomenon. Experientia 40:1173-1177 